\title{
The Right of Persons with Disability (RPWD) Bill 2016: Proactive Approach Needed to Empower Persons with Disability due to Mental Health Problems
}

\author{
Om Prakash Singh ${ }^{1}$, Ranjan Bhattacharyya ${ }^{2}$ \\ 1. Professor \& Head of the Department, Deptt of Psychiatry, NRS Medical College \& Hospital \\ 2. Assistant Professor \& Head of the Department, Deptt of Psychiatry \\ Murshidabad Medical College \& Hospital
}

\section{INTRODUCTION}

In "Rights of Persons With Disabilities (RPWD) Bill, Disability has been defined based on an evolving and dynamic concept and the types of disabilities have been increased from existing 7 to 21 and the Central Government will have the power to add more types of disabilities. ${ }^{1}$ The Speech and Language Disability and Specific Learning Disability have been added for the first time. Acid Attack Victims have been included. Dwarfism and muscular dystrophy have been indicated as separate class of specified disability. The New categories of disabilities also included three blood disorders, Thalassemia, Hemophilia and Sickle Cell disease. ${ }^{2}$ The Bill also provides for penalties for offences committed against persons with disabilities. Designated Special Courts have been proposed to handle cases concerning violation of rights of PWDs. Every child with benchmark disability between the age group of 6 and 18 years shall have the right to free education. The Rights of Persons with Disabilities Bill (RPWD 2016) - passed recently in both the Rajya Sabha and Lok Sabha - is a significant milestone. The 1995 Disability Law proved to be inadequate soon after it was passed. In fact, the Government started the process of amending the same soon after passing it. While this process dragged on for years, India ratified the United Nations Convention on the Rights of Persons with Disabilities (UNCRPD)in 2007 and this law is in condorcance with it $t^{3,4,5,6}$

\section{"RIGHTS OF PERSONS WITH DISABILITIES (RPWD) BILL}

Persons with Disabilities (Equal Opportunities, Protection of Rights and Full Participation) Act, 1995 is the principal Act for the empowerment of Persons with disabilities. India signed the United Nations Convention on the Rights of Persons with Disabilities (UNCRPD) and subsequently ratified the same on 1st October, 2007. The Convention came into effect on 3rd May 2008. Being a signatory to the Convention, India has an international obligation to comply with the provisions of the Convention. Keeping in view the fact that the existing Act of 1995 is not fully in conformity with the UNCRPD, a need was felt to have a rights-based legislation with a strong institutional mechanism. ${ }^{7,8,9}$

The Bill had been mooted by the Ministry of Social Justice and Empowerment after extensive consultation with various stakeholders, State Governments/UTs and concerned Central Ministries and Departments and was introduced in the Rajya Sabha on 7.2.2014, which was referred to the Parliamentary Standing Committee. RPWD Bill is definitely going to bring major positive changes in the lives of millions of disabled people in our country.

The Standing Committee submitted its recommendations on 7.5.2015. The Recommendations of the Standing Committee were also 
The Right of Persons with Disability (RPWD) Bill 2016

shared with the States/UTs as well as all concerned Central Ministries/Departments. Based on these consultations, amendments to the Bill have been proposed which would widen the scope of new Law and also provide a framework to enable the Persons with Disabilities to enjoy their enjoyment rights equally with others. ${ }^{12,13}$

The Union Cabinet in its meeting held on 30.11.2016 approved the proposal of the Department of Empowerment of Persons with Disabilities to incorporate these amendments in the Rights of Persons with Disabilities Bill, 2014 during the ongoing winter Session of Parliament. The new Bill with amendments proposes to repeal the existing Persons with Disabilities (Equal opportunities, Protection of Rights and Full Participation) Act, 1995. The Lok Sabha cleared the bill within two hours despite having previous long run demonetization debate. ${ }^{14,15,16}$

The salient features of the proposed Bill with amendments are as follows. ${ }^{17,18,19,20}$

i. Responsibility has been cast upon the appropriate governments to take effective measures to ensure that the persons with disabilities enjoy their rights equally with others.

ii. Disability has been defined based on an evolving and dynamic concept.

iii. The types of disabilities have been increased from existing 7 to 21 and the Central Government will have the power to add more types of disabilities (Table 1).

iv. Speech and Language Disability and Specific Learning Disability have been added for the first time. Acid Attack Victims have been included. Dwarfism, muscular dystrophy have been indicated as separate class of specified disability. The New categories of disabilities also included three blood disorders, Thalassemia, Hemophilia and Sickle Cell disease. v. Additional benefits have been provided for persons with benchmark disabilities and those with high support needs.

vi. Every child with benchmark disability between the age group of 6 and 18 years shall have the right to free education.

vii. For strengthening the Prime Minister's Accessible India Campaign, stress has been given to ensure accessibility in public buildings (both Government and private) in a prescribed time-frame.

viii. It has been proposed to increase reservation from $3 \%$ to $4 \%$ in Government jobs for certain persons or class of persons with benchmark disability.

ix. The Bill provides for grant of guardianship by District Court under which there will be joint decision - making between the guardian and the persons with disabilities.

x. Broad based Central \& State Advisory Boards on Disability have been proposed to be set up as policy making bodies.

xi. Strengthening of the Office of Chief Commissioner of Persons with Disabilities and State Commissioners of Disabilities has been proposed, which will act as regulatory bodies and Grievance Redressal agencies and also monitor implementation of the Act. These Offices will be assisted by an Advisory Committee comprising of experts in various disabilities.

xii. Creation of National and State Fund has been proposed to provide financial support to the persons with disabilities.

xiii. The Bill provides for penalties for offences committed against persons with disabilities.

xiv. Designated special Courts have been proposed to handle cases concerning violation of rights of PwDs. 
Table - 1

Type of disabilities incorporated in RPWD Bill.

\begin{tabular}{|l|l|}
\hline No. & \multicolumn{1}{|c|}{ Details } \\
\hline 1. & Blindness \\
2. & Low-vision \\
4. & Leprosy Cured persons \\
& Hearing Impairment \\
5. & (deaf and hard of hearing) \\
6. & Locomotor Disability \\
7. & Intellectual Disability \\
8. & Mental Illness \\
9. & Autism Spectrum Disorder \\
10. & Cerebral Palsy \\
11. & Muscular Dystrophy \\
12. & Chronic Neurological conditions \\
13. & Specific Learning Disabilities \\
14. & Multiple Sclerosis \\
15. & Speech and Language disability \\
16. & Thalassemia \\
17. & Hemophilia \\
18. & Sickle Cell disease \\
19. & Multiple Disabilities including deaf / \\
20. & blindness \\
21. & Acid Attack victim \\
\hline
\end{tabular}

A scheme of 'universal identity card for the disabled' is on the anvil and an agency has already been finalised for the purpose. The proposed card would also be linked to the Aadhar card to help the disabled all over the country. It provides for imprisonment of at least six months and up to two years, along with a fine ranging between Rs 10,000 and Rs 5 lakh for discriminating against differentlyabled persons. Out of 82 recommendations made by the Parliamentary Standing Committee, 59 were accepted by the Government. ${ }^{21,22}$
In the bill, disability has been defined based on an evolving and dynamic concept and the types of disabilities have been increased from existing seven to 21 . The Centre will have the power to add more types of disabilities to it.

It also strengthens the office of chief commissioner and state commissioners for Persons with Disabilities which will act as regulatory bodies.

The Indian Penal Code on violence against women already includes disability-specific clauses. But, for the very first time in India, we have gender-specific clauses as part of disability legislation. One needs to highlight here that the provisions for women are not restricted to one particular chapter, but are integrated in many important chapters like Health, Social Security, and others. This Bill says that "appropriate Governments shall, within the limit of their economic capacity and development, formulate necessary schemes and programmes to safeguard and promote the rights of persons with disabilities for adequate standard of living, to enable them to live independently or in the community." This is a marked improvement as the old law only talked about affirmative actions like reservation in jobs and employment. $^{23,24}$

There are worries about the words "within the limit of its economic capacity", and activists are already working to see that the rules under this new law are framed in such a manner that the stipulation that "the quantum of assistance to the persons with disabilities under such schemes and programmes shall be at least $25 \%$ higher than the similar schemes applicable to others" is applied to all poverty alleviation schemes as mentioned in this law henceforth.Unfortunately, some in the disability sector don't see this law as a reason for celebration. There are some who feel that the law should have been closer to the UNCRPD's spirit. There are even certain conflicting clauses in this law. For example, it says, "The appropriate Government shall ensure that the persons with disabilities enjoy legal capacity on an equal basis with others in all aspects of life 
and have the right to equal recognition everywhere as any other person before the law," and yet it also talks about the provision of guardianship for certain kinds of disabled people, baffling lots of activists. However, perhaps it is important to read this law in conjunction with another law - namely the National Trust Act - under which guardianship has been mandated till date. $25,26,27$

In our country, the disabled have to procure a certificate to get any kind of entitlement from the state. The process to procure certification is extremely difficult and time-consuming. Moreover, authorities do not accept the certificate from one state in another. For example, the blind cricket team from West Bengal realised they would not get concessional bus fares in Karnataka. However, this law is bringing in much-needed change. The RPWD Bill provides that henceforth such certificates "will be valid across the country". The old disability law never realised its full potential because of the lack of penalty provisions, among other things. Though the provisions could have more teeth, their inclusion is definite progress from the existing law. The legal procedure of our country is expensive, and poor people have little access to courts. ${ }^{28,29}$

This law mandates accessibility for even private establishments, and gives a specific timeframe to implement the changes. From transportation to internet access to electronic goods, the law makes accessibility mandatory across the board.

Role of Psychiatrists - There has been a marked delay in providing disability benefit to Persons with Mental Illness even after notification of disability benefits. It was mainly due to the absence of any structured assessment tool. Notification of IDEAS filled this gap. However there was reluctance and lack of awareness leading to delay of years in providing certificates leading to denial of benefits. RPWD 2016 now incorporates Autism Spectrum Disorder (sl no 9), Specific Learning Disabilities (SL 13), Speech and Language disabilities (SL 15), in addition to Intellectual Disabilities (SL no 7) and Mental Illness (SL no 8). We should actively engage with the Government to notify assessment norms. In the meantime, since there are assessment tools available for assessment of these disorders we should facilitate the certification process so that the benefit reaches to the target population without delay.

\section{REFERENCES}

1. World Health Organization. World Report on Disability. Geneva : World Health Organization; 2011

2. UNCRPD. United Nations Convention on the Rights of Persons with Disabilities; 2006. Available from : http : // www2.ohchr.org/english/law/disabilities-convention. htm. [Last accessed on 2016 Jan 28].

3. Math SB, Nirmala MC. Stigma haunts persons with mental illness who seek relief as per Disability Act 1995. Indian J Med Res 2011; $134:$ 128-30. [PUBMED]

4. Rao GP, Ramya VS, Bada MS. The rights of persons with Disability Bill, 2014: How "enabling" is it for persons with mental illness?. Indian J Psychiatry 2016;58:121-8

5. Math SB, Murthy P, Chandrashekar CR. Mental health act (1987) : Need for a paradigm shift from custodial to community care. Indian J Med Res 2011; 133 : 246-9.

6. NHRC. National Human Rights Commission (NHRC). Available from : http ://www.nhrc.nic.in/. [Last accessed on 2016 Feb 04].

7. Math SB, Nagaraja D. Mental health legislation: An Indian perspective. In : Murthy $\mathrm{P}$, Nagaraja D, editors. Mental Health; Human Rights. Bangalore, New Delhi : National Institute of Mental Health and Neuro Sciences, National Human Rights Commission; 2008.

8. World Health Organization. WHO Resource Book on Mental Health, Human Rights and Legislation. Geneva: World Health Organization; 2005.

9. Shakespeare T. The social model of disability. The Disability Studies Reader. Vol. 2. New York: Routledge, Taylor \& Francis Group; 2006. p. 197-204.

10. Drew N, Funk M, Tang S, Lamichhane J, Chávez E, Katontoka S, et al. Human rights violations of people with mental and psychosocial disabilities: An unresolved global crisis. Lancet 2011; 378 : 1664-75.

11. Buist-Bouwman MA, De Graaf R, Vollebergh WA, Alonso J, Bruffaerts R, Ormel J; ESEMeD/MHEDEA Investigators. Functional disability of mental disorders and comparison with physical disorders: A study among the general population of six European countries. Acta Psychiatr Scand 2006; 113 : 492-500.

12. Demyttenaere K, Bruffaerts R, Posada-Villa J, Gasquet I, Kovess V, Lepine JP, et al. Prevalence, severity, and unmet need for treatment of mental disorders in the World Health Organization World Mental Health Surveys. JAMA 2004; 291 : 2581-90. 
13. Goetzel RZ, Long SR, Ozminkowski RJ, Hawkins K, Wang S, Lynch W. Health, absence, disability, and presenteeism cost estimates of certain physical and mental health conditions affecting US employers. J Occup Environ Med 2004; 46 : 398412.

14. Sen A. The Idea of Justice. Cambridge, Massachusetts: Harvard University Press; 2011.

15. Insel TR. Assessing the economic costs of serious mental illness. Am J Psychiatry 2008; 165 : 663-5.

16. Barker PR, Manderscheid RW, Hendershot GE, Jack SS, Schoenborn CA, Goldstrom I. Serious mental illness and disability in the adult household population : United States, 1989. Adv Data 1992; 218 : 1-11.

17. Drake RE, Skinner JS, Bond GR, Goldman HH. Social security and mental illness : Reducing disability with supported employment. Health Aff (Millwood) 2009; 28 : 761-70.

18. Sanderson K, Andrews G. Prevalence and severity of mental health-related disability and relationship to diagnosis. Psychiatr Serv 2002; 53 : 80-6.

19. Stuart H. Mental illness and employment discrimination. Curr Opin Psychiatry 2006; 19 : 522-6.

20. Ustün TB, Chatterji S, Kostansjek N, Bickenbach J. WHO's ICF and functional status information in health records. Health Care Financ Rev 2003; 24 : 77-88.

21. Hendriks SM, Spijker J, Licht CM, Beekman AT, Hardeveld F, de Graaf R, et al. Disability in anxiety disorders. J Affect Disord 2014; 166 : 227-33.

22. Gururaj GP, Math SB, Reddy JY, Chandrashekar CR. Family burden, quality of life and disability in obsessive compulsive disorder: An Indian perspective. J Postgrad Med 2008; 54 : 91-7.
23. Judd LL, Akiskal HS, Zeller PJ, Paulus M, Leon AC, Maser JD, et al. Psychosocial disability during the long-term course of unipolar major depressive disorder. Arch Gen Psychiatry $2000 ; 57: 375-80$.

24. Frueh BC, Elhai JD, Gold PB, Monnier J, Magruder KM, Keane TM, et al. Disability compensation seeking among veterans evaluated for posttraumatic stress disorder. Psychiatr Serv 2003; 54 S: 84-91.

25. Whiteford HA, Degenhardt L, Rehm J, Baxter AJ, Ferrari AJ, Erskine HE, et al. Global burden of disease attributable to mental and substance use disorders: Findings from the global burden of disease study 2010. Lancet 2013; 382 : 1575-86.

26. Patel V, Kleinman A. Poverty and common mental disorders in developing countries. Bull World Health Organ 2003; 81 : 609-15.

27. Thornicroft G, Brohan E, Rose D, Sartorius N, Leese M; INDIGO Study Group. Global pattern of experienced and anticipated discrimination against people with schizophrenia: A cross-sectional survey. Lancet 2009; 373 : 408-15.

28. Koschorke M, Padmavati R, Kumar S, Cohen A, Weiss HA, Chatterjee S, et al. Experiences of stigma and discrimination of people with schizophrenia in India. Soc Sci Med 2014; 123 : 149-59.

29. Sartorius N. Stigma and mental health. Lancet 2007; 370 : 810-1.

30. Saxena S, Thornicroft G, Knapp M, Whiteford H. Resources for mental health : Scarcity, inequity, and inefficiency. Lancet 2007; 370 : 878-89.

31. Maj M. The rights of people with mental disorders: WPA perspective. Lancet 2011; 378 : 1534-5.

32. Thara R, Srinivasan TN. How stigmatising is schizophrenia in India? Int J Soc Psychiatry 2000; $46: 135-41$. 